\title{
Congenital Methemoglobinemia
}

National Cancer Institute

\section{Source}

National Cancer Institute. Congenital Methemoglobinemia. NCI Thesaurus. Code C98898.

Methemoglobinemia inherited in an autosomal recessive pattern. It is caused by deficiency of the enzyme NADH methemoglobin reductase or the presence of abnormal hemog lobin M. It presents with cyanosis early in life. There is no evidence of cardiopulmonary disease present. 